\title{
Produksi dan Kualitas Umbi Beberapa Genotipe Kentang (Solanum tuberosum L.) Koleksi IPB untuk Olahan Keripik Kentang
}

\author{
Yield and Tuber Quality Potato (Solanum tuberosum L.) \\ of IPB Collection for Potato Chips Industries
}

\author{
Awang Maharijaya ${ }^{1,2^{*}}$, Linda Nur Salma ${ }^{2}$, dan Shandra Amarillis ${ }^{1}$ \\ ${ }^{1}$ Departemen Agronomi dan Hortikultura, Fakultas Pertanian, Institut Pertanian Bogor \\ (IPB University), Jl. Meranti, Kampus IPB Darmaga, Bogor 16680, Indonesia \\ ${ }^{2}$ Pusat Kajian Hortikultura Tropika, LPPM IPB. Kampus Baranangsiang IPB \\ Jl. Pajajaran Bogor, Indonesia
}

Diterima 21 Oktober 2020/Disetujui 11 Desember 2020

\begin{abstract}
The need for potato varieties for the potato chip processing industry continues to increase; however, the availability of varieties that produce tubers that meet the criteria for potato chips is still limited. The study aimed to characterize the quality of potato tubers from several superior genotypes of IPB collections that are suitable for the potato chip processing industry's needs. These quality characters included tuber diameter, specific gravity, dry matter, and organoleptic chips. This research was conducted in January-May 2020 at the Margamulya village, Cikajang, Garut. Eight genotypes, PKHT-2019010, PKHT-2019-011, PKHT-2019-012, PKHT-2019-013, PKHT-2019-014, PKHT-2019-015, PKHT-2019-016, PKHT-2019017 with two control varieties, Medians and Intan were used in this study as material plant. The genotype was used as a single factor in a randomized complete block design with four replications. The study begins with preparing the land, planting, maintenance, harvesting, and processing of chips. The results showed that the PKHT-2019-010, PKHT-2019-012, and PKHT2019-017 genotypes had potential as genotypes that could be developed as potato varieties for raw materials for the potato chip industry based on density, sugar content, shape, appearance, and good color chips. The PKHT-2019-015 genotype has excellent productivity, tuber weight, and tuber diameter and meets industrial criteria, but has high sugar content, so it is more suitable to be developed as vegetable potatoes. However, further research is still needed to increase the three genotypes' weight and size to reach industry standards.
\end{abstract}

Keywords: genotype, crispness, productivity, sugar content

\section{ABSTRAK}

Kebutuhan akan varietas kentang untuk industri olahan keripik kentang terus meningkat, namun ketersediaan varietas yang menghasilkan umbi yang memenuhi kriteria untuk keripik kentang masih terbatas. Penelitian ini bertujuan melakukan karakterisasi kualitas umbi kentang dari beberapa genotipe unggul koleksi IPB yang sesuai bagi kebutuhan industri olahan keripik kentang. Karakter kualitas tersebut meliputi diameter umbi, berat jenis, bahan kering, dan organoleptik keripik. Penelitian dilaksanakan pada Januari-Mei 2020 di Desa Margamulya, Kecamatan Cikajang, Kabupaten Garut. Sebanyak delapan genotipe yang terdiri atas PKHT-2019-010, PKHT-2019-011, PKHT-2019-012, PKHT-2019-013, PKHT-2019-014, PKHT-2019-015, PKHT-2019-016, PKHT-2019-017 dan dua varietas pembanding yaitu Medians dan Intan. Rancangan percobaan yang digunakan pada penelitian ini adalah rancangan kelompok lengkap teracak faktor tunggal yaitu genotipe dengan 4 ulangan. Penelitian dimulai dari persiapan lahan, penanaman, pemeliharaan, dan pemanenan, serta pengolahan keripik. Hasil penelitian menunjukkan bahwa genotipe PKHT-2019-010, PKHT-2019-012, dan PKHT-2019-017 memiliki potensi sebagai genotipe yang dapat dikembangkan sebagai varietas kentang untuk bahan baku industri keripik kentang berdasarkan berat jenis, kandungan gula, bentuk, penampilan dan warna keripik yang baik. Genotipe PKHT-2019-015 memiliki produktivitas, bobot umbi dan diameter umbi yang sangat baik dan memenuhi kriteria industri, namun memiliki kadar gula yang tinggi sehingga lebih cocok dikembangkan sebagai kentang sayur. Namun demikian masih diperlukan penelitian lanjutan untuk meningkatkan bobot dan ukuran ketiga genotipe tersebut untuk mencapai standard industri.

Kata kunci: genotipe, kerenyahan, produktivitas, kandungan gula

\footnotetext{
*Penulis untuk korespondensi. e-mail: awangmaharijaya@apps.ipb.ac.id
} 


\section{PENDAHULUAN}

Kentang (Solanum tuberosum L.) merupakan komoditas hortikultura yang dapat menjadi alternatif pangan dan berpotensi untuk dikembangkan karena memiliki nilai ekonomi tinggi sebagai bahan baku industri (Gunarto, 2012; Kusandriani, 2014). Industri olahan kentang mengalami perkembangan ditandai meningkatnya permintaan bahan baku keripik (Asgar, 2013). Industri keripik kentang telah berkembang di sentra produksi seperti di Pangalengan, Garut, Banjarnegara, dan Pasuruan (Kusmana, 2012). Produksi kentang Indonesia relatif rendah dibandingkan dengan Eropa yang mencapai 25.5 ton ha $^{-1}$, sedangkan Indonesia baru mencapai 18.7 ton ha ${ }^{-1}$ (Sabarella et al., 2017).

Jumlah impor kentang tahun 2016 adalah 106,230 ton mengalami kenaikan $4.6 \%$ dari tahun 2015 sebanyak 101,558 ton (Kementan, 2017). Jumlah impor yang tinggi disebabkan oleh berkembangnya industri pengolahan kentang yang belum diimbangi oleh kenaikan produksi (Harahap et al., 2018). Produksi berfluktuasi, pada 20162017 mengalami penurunan yaitu 1.21 juta ton menjadi 1.16 juta ton dan kembali meningkat tahun 2018 dan 2019 menjadi 1.28 juta ton dan 1.31 juta ton (Kementan, 2019). Bahan baku untuk olahan kentang masih jarang diusahakan dan pengusahaannya masih dalam bentuk kemitraan serta terbatasnya benih bermutu di kalangan petani menyebabkan industri kentang di Indonesia mengalami kesulitan (Kusandriani, 2014; Amarullah et al., 2019). Kentang untuk bahan baku olahan masih menggunakan varietas Atlantik karena memiliki bahan kering tinggi dan rasa yang enak sehingga cocok untuk olahan, namun memiliki kelemahan peka terhadap penyakit (Purwito dan Wattimena, 2008).

Bahan baku kentang olahan harus memenuhi persyaratan kualitas dan kriteria tertentu, serta penggunaan jenis kentang yang tepat (Asgar et al., 2011). Karakteristik mutu keripik kentang dilihat dari penampilan yang baik, tekstur keripik (renyah), dan kandungan gizinya (Mendei dan Nuryadi, 2017). Standar mutu bahan baku yang diminta industri keripik nasional adalah umbi dengan kriteria umbi dengan bobot per umbi 101-300 $\mathrm{g}$ (Thoriq, 2018), diameter 5-7 cm, berat jenis minimal $1.07 \mathrm{~g} \mathrm{~cm}^{3}$, bahan kering $16.7 \%$ (Kusmana dan Basuki, 2004), kandungan gula $<0.05 \%$, bentuk umbi yang baik, dan permukaan rata (Asgar et al., 2016). Menurut Kurniawan dan Suganda (2014), kentang yang memenuhi syarat untuk olahan keripik adalah kentang dengan kandungan total padatan $20-22 \%$ dan kandungan pati $14-16 \%$.

Pengembangan varietas unggul kentang mulai banyak di Indonesia. Menurut Neni et al. (2018), Pusat Kajian Hortikultura Tropika (PKHT) dan Departemen Agronomi dan Hortikultura, IPB telah merakit genotipe di antaranya PKHT-2, PKHT-3, PKHT-4, PKHT-6, dan PKHT-9. Diantara hasil pemuliaan kentang PKHT memungkinkan untuk digunakan sebagai bahan baku keripik kentang. Penelitian ini bertujuan melakukan karakterisasi kualitas dan produksi umbi kentang IPB dari beberapa genotipe unggul PKHT yang sesuai bagi kebutuhan industri olahan keripik kentang.

\section{BAHAN DAN METODE}

Penelitian dilaksanakan di Kecamatan Cikajang, Kabupaten Garut pada Januari-Mei 2020. Bahan tanaman yang digunakan adalah benih kentang umbi G2 bobot 8$30 \mathrm{~g}$, telah melewati masa dormansi ditandai adanya tunas dengan panjang tunas rata-rata $1 \mathrm{~cm}$. Bahan tanaman yang digunakan pada penelitian ini adalah genotipe koleksi Institut Pertanian Bogor (IPB) yakni: PKHT-2019-010, PKHT2019-011, PKHT-2019-012, PKHT-2019-013, PKHT-2019014, PKHT-2019-015, PKHT-2019-016, PKHT-2019-017, serta varietas Medians dan Intan sebagai pembanding. Pupuk yang digunakan terdiri atas pupuk kandang ayam (29 ton ha ${ }^{-1}$ ). Pupuk NPK 15:15:15 (400 kg ha $\left.{ }^{-1}\right)$, ZA (320 $\left.\mathrm{kg} \mathrm{ha}^{-1}\right)$, dan TSP $\left(320 \mathrm{~kg} \mathrm{ha}^{-1}\right)$ sesuai anjuran penyuluh pertanian setempat kepada petani kentang pada umumnya. Peralatan yang digunakan terdiri atas alat budidaya pertanian, timbangan, meteran, jangka sorong, termometer, refraktometer, mini Royal Horticulture Society Color Chart (RHSCC), dan alat pengolahan keripik kentang.

Penelitian menggunakan rancangan kelompok lengkap teracak faktor tunggal dengan genotipe sebagai perlakuan. Setiap perlakuan percobaan terdapat empat ulangan dan setiap satuan percobaan terdapat 24 tanaman. Penanaman dilakukan dengan menanam satu benih per lubang tanam dengan jarak tanam $50 \mathrm{~cm}$ x $28 \mathrm{~cm}$ (Kusandriani, 2014) pada luas lahan $218.4 \mathrm{~m}^{2}$. Kelas umbi berdasarkan bobot satuan umbi, $\mathrm{XL}>40 \mathrm{~g}, \mathrm{~L}=30-40 \mathrm{~g}, \mathrm{M}=20-30 \mathrm{~g}, \mathrm{~S}=10$ $20 \mathrm{~g}, \mathrm{XS}=1-10 \mathrm{~g}$; kelas umbi berdasarkan diameter $\mathrm{XL}=$ 6- $>7 \mathrm{~cm}, \mathrm{~L}=5-5.9 \mathrm{~cm}, \mathrm{M}=4-4.9 \mathrm{~cm}, \mathrm{~S}=3-3.9 \mathrm{~cm}, \mathrm{XS}=$ 2-2.9 cm, XXS $=<2 \mathrm{~cm}$ (Neni, 2017). Grading dilakukan untuk menentukan bobot dan diameter umbi berbagai ukuran untuk mempermudah pengolahan sebagai syarat mutu umbi untuk keripik. Pengolahan keripik kentang dilakukan mulai dari mencuci umbi, mengupas kulit umbi, dan mengiris umbi dengan ketebalan 1-1.5 mm. Umbi hasil irisan dicuci dan digoreng dalam minyak panas dengan suhu $165-180^{\circ} \mathrm{C}$ sekitar 4-5 menit. Penilaian organoleptik kentang dilakukan oleh 15 panelis merujuk pada penelitian Asgar et al. (2016). Kriteria panelis adalah pria dan wanita berumur 20-40 tahun. Variabel tanaman yang diamati meliputi pengamatan vegetatif (tinggi tanaman, diameter batang, jumlah cabang, dan daun) pada 49 HST, pengamatan produksi, karakteristik umbi (jumlah, bobot, diameter, berat jenis, dan kadar gula), organoleptik umbi (bentuk, warna kulit dan daging), serta organoleptik keripik (warna, rasa, kerenyahan, dan aroma). Data pengamatan yang diperoleh dianalisis menggunakan uji F. Jika uji F menunjukkan pengaruh nyata pada taraf 5\%, dilakukan uji lanjut menggunakan Duncan Multiple Range Test (DMRT).

\section{HASIL DAN PEMBAHASAN}

Umbi sebagai bahan baku keripik kentang harus memenuhi standar kualitas mutu tertentu (Asgar et al., 2011). Berdasarkan Tabel 1, rata-rata genotipe memiliki berat jenis $1.05-1.26 \mathrm{~g} \mathrm{~mL}^{-1}$. PKHT-2019-010 memiliki berat jenis paling tinggi, yaitu $1.26 \mathrm{~g} \mathrm{~mL}^{-1}$. Menurut Asgar (2013), industri keripik kentang PT Indofood menetapkan 
standar berat jenis minimum $1.07 \mathrm{~g} \mathrm{~mL}^{-1}$. Semua genotipe kentang IPB cocok untuk keripik kentang, kecuali Medians karena memiliki berat jenis di bawah standar, yaitu $1.05 \mathrm{~g}$ $\mathrm{mL}^{-1}$. Hasil ini tidak berbanding lurus dengan Kusandriani (2014) yang meyatakan Medians sangat cocok digunakan untuk bahan baku industri keripik kentang karena memiliki keunggulan dibandingkan Atlantik.

Kriteria penting untuk bahan baku keripik kentang selain berat jenis adalah kandungan gula pada umbi. Berdasarkan Tabel 1, PKHT-2019-015 memiliki kandungan gula tertinggi sebesar $6.5 \%$ yang tidak berbeda nyata dengan Intan sebagai kentang konsumsi (7\%). Kentang konsumsi mempunyai kadar gula dan kadar air yang tinggi sehingga mengurangi tekstur renyah (Hidayat et al., 2018). PKHT2019-012 dan PKHT-2019-014 memiliki kandungan gula yang rendah mendekati Medians sehingga dapat menjadi alternatif untuk olahan keripik. Namun, PKHT-2019-014 memiliki kerentanan terhadap penyakit sehingga tidak mampu menghasilkan produksi yang maksimal. Kandungan gula PKHT-2019-010 dan PKHT-2019-017 lebih rendah dibandingkan varietas Intan sehingga diindikasikan memiliki kandungan gula yang rendah dan dapat menjadi alternatif untuk kentang olahan. Menurut Kurniawan dan Suganda (2014), kadar gula berpengaruh pada kualitas hasil terutama penampilan kentang.

Hasil penilaian (Tabel 1) menunjukkan keripik Medians lebih disukai karena kerenyahan dan penampilan keripik yang sangat baik. Penilaian kerenyahan keripik PKHT-2019-010, PKHT-2019-013, PKHT-2019-014, dan PKHT-2019-017 tidak berbeda nyata dengan Medians, yaitu 4.1-4.5. Menurut Yulian (2018), kerenyahan keripik kentang dipengaruhi oleh kandungan pati karena berkaitan dengan kekerasan umbi Namun, pada penelitian ini belum dilakukan pengujian kadar pati sehingga belum ditemukan korelasi antara kadar pati dengan kerenyahan. Penampilan keripik yang paling disukai adalah Medians (4.4) dan memiliki nilai sama secara statistik dengan PKHT-2019-010 (4.2) dan PKHT-2019-017 (4.4). Penilaian rasa dan aroma berkisar 3.1-3.9 dan 3.2-3.9 yang berarti rasa dan aroma kentang semua genotipe tergolong cukup sampai baik.

\section{Karakteristik Pertumbuhan Vegetatif}

Bahan baku kentang yang berkualitas dan sesuai untuk keripik dapat dipenuhi dari hasil budidaya yang baik (Asgar et al., 2011). Berdasarkan Tabel 2, semua genotipe kentang IPB menunjukkan daya tumbuh yang baik $95-100 \%$ pada saat umur tanaman 17 hari setelah tanam (HST), kecuali pada PKHT-2019-014, PKHT-2019-015, dan PKHT-2019016 yang terlambat tumbuh karena benih belum pecah dormansi tunas. PKHT-2019-015 memiliki tinggi tanaman dan diameter batang tertinggi, yaitu $64.54 \mathrm{~cm}$ dan $12.99 \mathrm{~mm}$ yang tidak berbeda nyata dengan PKHT-2019-010 (60.62 $\mathrm{cm})$ dan PKHT-2019-017 (59.54 cm). PKHT-2019-017 memiliki jumlah cabang dan jumlah daun tertinggi, yaitu 19.8 cabang dan 183.5 helai daun yang tidak berbeda nyata dengan PKHT-2019-010, PKHT-2019-012, PKHT-2019013, PKHT-2019-015, PKHT-2019-016.

\section{Panen dan Hasil Panen}

Hujan dengan intensitas tinggi menyebabkan tingginya serangan penyakit karena mendukung perkembangan dan penyebaran penyakit. (Utami et al., 2015; Zulkarnain et al., 2017). Genotipe kentang IPB rata-rata dipanen pada umur 90-98 HST kecuali PKHT-2019-011 yang dipanen lebih cepat pada 69 HST karena terinfeksi penyakit layu fusarium akibat intensitas hujan yang relatif tinggi. Waktu panen PKHT-2019-015 diperkirakan lebih dari 100 HST, diindikasikan dari kulit umbi yang dipanen belum kuat

Tabel 1. Karaktristik kualitas umbi dan penilaian organoleptik keripik kentang

\begin{tabular}{|c|c|c|c|c|c|c|}
\hline Genotipe & $\begin{array}{c}\text { Berat jenis } \\
\left(\mathrm{g} \mathrm{mL}^{-1}\right)\end{array}$ & $\begin{array}{c}\text { Kadar brix } \\
(\%)\end{array}$ & Kerenyahan ${ }^{\mathrm{a}}$ & $\operatorname{Rasa}^{\mathrm{a}}$ & Aroma $^{\mathrm{a}}$ & Penampilan $^{\mathrm{a}}$ \\
\hline PKHT-2019-010 & 1.26 & $5.8 \mathrm{cde}$ & $4.1 \mathrm{abcd}$ & 3.9 & 3.7 & $4.3 \mathrm{ab}$ \\
\hline PКНT-2019-011 & 1.16 & $5.8 \mathrm{cde}$ & $3.7 \mathrm{de}$ & 3.7 & 3.6 & $3.6 \mathrm{c}$ \\
\hline РКНТ-2019-012 & 1.16 & $5.3 \mathrm{ef}$ & $3.9 \mathrm{bcd}$ & 3.6 & 3.7 & $3.7 \mathrm{bc}$ \\
\hline PKHT-2019-013 & 1.15 & $6.3 \mathrm{bc}$ & 4.1abcd & 3.6 & 3.3 & $3.8 \mathrm{bc}$ \\
\hline PKHT-2019-014 & 1.12 & $5.5 \mathrm{def}$ & $4.4 \mathrm{abc}$ & 3.9 & 3.9 & $4.0 \mathrm{abc}$ \\
\hline PKHT-2019-015 & 1.14 & $6.5 \mathrm{ab}$ & $3.9 \mathrm{bcd}$ & 3.5 & 3.2 & $3.7 \mathrm{bc}$ \\
\hline PКНT-2019-016 & 1.08 & $6.3 \mathrm{bc}$ & $3.1 \mathrm{e}$ & 3.1 & 3.5 & $3.7 \mathrm{bc}$ \\
\hline PКНТ-2019-017 & 1.06 & $6.0 \mathrm{bcd}$ & $4.5 \mathrm{ab}$ & 3.6 & 3.5 & $4.2 \mathrm{abc}$ \\
\hline MEDIANS & 1.05 & $5.0 \mathrm{f}$ & $4.6 \mathrm{a}$ & 3.7 & 3.5 & $4.4 \mathrm{a}$ \\
\hline INTAN & 1.13 & $7.0 \mathrm{a}$ & $3.8 \mathrm{~cd}$ & 3.5 & 3.7 & $3.8 \mathrm{bc}$ \\
\hline Uji F & tn & $* *$ & $* *$ & tn & tn & $*$ \\
\hline
\end{tabular}

Keterangan: ${ }^{N}$ Nilai dalam kolom menunjukkan 1=sangat kurang; $2=$ kurang; 3 = cukup; 4 = baik; 5 = sangat baik. Angka-angka pada kolom yang sama yang diikuti oleh huruf yang sama tidak berbeda nyata pada DMRT taraf $\alpha=5 \%$, th $=$ tidak berpengaruh nyata, $*$ = berpengaruh nyata, $* *=$ berpengaruh sangat nyata 
Tabel 2. Karakteristik pertumbuhan tanaman kentang dari setiap genotipe kentang

\begin{tabular}{|c|c|c|c|c|c|}
\hline Genotipe & $\begin{array}{c}\text { Bibit hidup } \\
(\%)\end{array}$ & $\begin{array}{l}\text { Tinggi tanaman } \\
(\mathrm{cm})\end{array}$ & $\begin{array}{c}\text { Diameter batang } \\
(\mathrm{mm})\end{array}$ & Jumlah cabang & $\begin{array}{c}\text { Jumlah daun } \\
\text { (helai) }\end{array}$ \\
\hline PKHT-2019-010 & $100.0 \mathrm{a}$ & $60.62 a$ & $10.00 \mathrm{bc}$ & $19.0 \mathrm{ab}$ & $147.3 \mathrm{abc}$ \\
\hline PKHT-2019-011 & $100.0 \mathrm{a}$ & $50.29 b$ & $10.99 b$ & $13.0 \mathrm{c}$ & $93.3 \mathrm{c}$ \\
\hline РКHT-2019-012 & $100.0 \mathrm{a}$ & $46.4 \mathrm{bc}$ & $8.49 \mathrm{de}$ & $14.3 \mathrm{abc}$ & $127.8 \mathrm{abc}$ \\
\hline РКНТ-2019-013 & $95.8 \mathrm{a}$ & $39.82 \mathrm{~cd}$ & $6.83 \mathrm{~g}$ & $14.5 \mathrm{abc}$ & $113.8 \mathrm{bc}$ \\
\hline РКНТ-2019-014 & $17.4 \mathrm{~d}$ & $37.11 \mathrm{de}$ & $8.10 \mathrm{ef}$ & $12.8 \mathrm{c}$ & $89.8 \mathrm{c}$ \\
\hline PKHT-2019-015 & $29.2 \mathrm{c}$ & $64.54 \mathrm{a}$ & $12.99 \mathrm{a}$ & $19.0 \mathrm{ab}$ & $162.8 \mathrm{ab}$ \\
\hline PKHT-2019-016 & $75.0 \mathrm{~b}$ & $31.03 \mathrm{e}$ & $7.08 \mathrm{fg}$ & $14.0 \mathrm{abc}$ & $106 \mathrm{bc}$ \\
\hline PKHT-2019-017 & $100.0 \mathrm{a}$ & $59.54 \mathrm{a}$ & $9.05 \mathrm{cde}$ & $19.8 \mathrm{a}$ & $183.5 \mathrm{a}$ \\
\hline MEDIANS & $100.0 \mathrm{a}$ & $36.75 \mathrm{de}$ & $9.59 \mathrm{~cd}$ & $13.8 \mathrm{bc}$ & $92.8 \mathrm{c}$ \\
\hline INTAN & $100.0 \mathrm{a}$ & $37.54 \mathrm{de}$ & $8.08 \mathrm{ef}$ & $13.5 \mathrm{bc}$ & $101.8 \mathrm{c}$ \\
\hline Uji F & $* *$ & $* *$ & $* *$ & $*$ & $* *$ \\
\hline
\end{tabular}

Keterangan: Angka-angka pada kolom yang sama yang diikuti oleh huruf yang sama tidak berbeda nyata pada DMRT taraf $\alpha=5 \%$, $=$ berpengaruh nyata, $* *=$ berpengaruh sangat nyata

dan mudah mengelupas. Waktu panen yang lebih cepat dilakukan untuk menyelamatkan hasil umbi dari serangan hama orong-orong dan penyakit layu bakteri.

Berdasarkan Tabel 3 produktivitas dan bobot pertanaman tertinggi adalah genotipe PKHT-2019-015, yaitu 51.41 ton $\mathrm{ha}^{-1}$ dan 823.83 g. Produktivitas dan bobot per tanaman kedua tertinggi adalah PKHT-2019-010 (33.67 ton $\mathrm{ha}^{-1}$ dan $494.30 \mathrm{~g}$ ) serta PKHT-2019-017 (32.20 ton ha ${ }^{-1}$ dan 510.93 g). Tanaman PKHT-2019-014 dan PKHT-2019013 menunjukkan serangan layu bakteri paling parah yang menyebabkan tanaman banyak yang mati sebelum masuk usia panen, sehingga umbi yang dihasilkan tidak maksimal, yaitu 9.25 ton ha-1 dan 10.55 ton ha-1. Menurut Duaja (2012), waktu pengisian umbi yang lebih pendek menyebabkan rendahnya bobot umbi. PKHT-2019-017 dan PKHT-2019010 menghasilkan jumlah umbi per tanaman paling banyak, yaitu $16.8 \mathrm{knol}$ dan $16.3 \mathrm{knol}$ (Tabel 3), namun bobot per satuan umbi PKHT-2019-010 (60.51 g) dan PKHT-2019017 (64.73 g) berbeda nyata lebih kecil dari PKHT-2019015 (140.87 g). Menurut Neni (2017), umbi dengan jumlah yang banyak namun menghasilkan bobot umbi per tanaman yang kecil disebabkan rataan bobot per satuan umbi yang kecil.

Pada penelitian ini bobot umbi berkorelasi positif dengan diameter umbi $(\mathrm{P}<0.05)$. Dengan demikian baik bobot tumbi dan diameter umbi dapat digunakan untuk menentukan kriteria kesesuaian dengan industri keripik kentang. Industri keripik kentang sesuai standar nasional

Tabel 3. Produktivitas dan karakteristik umbi kentang genotipe IPB

\begin{tabular}{lcccccc}
\hline Genotipe & $\begin{array}{c}\text { Bobot umbi } \\
\text { per hektar } \\
\left(\text { ton ha }^{-1}\right)\end{array}$ & $\begin{array}{c}\text { Bobot umbi } \\
\text { per tanaman } \\
(\mathrm{g})\end{array}$ & $\begin{array}{c}\text { Jumlah umbi } \\
\text { per tanaman } \\
(\mathrm{knol})\end{array}$ & $\begin{array}{c}\text { Bobot per } \\
\text { satuan umbi } \\
(\mathrm{g})\end{array}$ & $\begin{array}{c}\text { Diameter per } \\
\text { satuan umbi } \\
(\mathrm{cm})\end{array}$ & $\begin{array}{c}\text { Panjang umbi } \\
(\mathrm{cm})\end{array}$ \\
\hline PKHT-2019-010 & $33.67 \mathrm{~b}$ & $494.30 \mathrm{~b}$ & $16.3 \mathrm{a}$ & $60.51 \mathrm{~cd}$ & $4.34 \mathrm{~cd}$ & $6.68 \mathrm{abc}$ \\
PKHT-2019-011 & $12.20 \mathrm{de}$ & $140.70 \mathrm{e}$ & $7.3 \mathrm{~d}$ & $52.98 \mathrm{~cd}$ & $3.78 \mathrm{de}$ & $6.27 \mathrm{bcd}$ \\
PKHT-2019-012 & $21.24 \mathrm{~cd}$ & 332.85 & $11.8 \mathrm{bc}$ & $57.89 \mathrm{~cd}$ & $3.8 \mathrm{de}$ & $7.71 \mathrm{a}$ \\
PKHT-2019-013 & $10.55 \mathrm{e}$ & $126.60 \mathrm{e}$ & $8.5 \mathrm{bcd}$ & $33.75 \mathrm{~d}$ & $3.53 \mathrm{e}$ & $4.65 \mathrm{e}$ \\
PKHT-2019-014 & $9.25 \mathrm{e}$ & $129.00 \mathrm{e}$ & $7.5 \mathrm{~cd}$ & $38.36 \mathrm{~d}$ & $3.35 \mathrm{e}$ & $5.67 \mathrm{cde}$ \\
PKHT-2019-015 & $51.41 \mathrm{a}$ & $823.83 \mathrm{a}$ & $9.5 \mathrm{bcd}$ & $140.87 \mathrm{a}$ & $6.55 \mathrm{a}$ & $7.39 \mathrm{a}$ \\
PKHT-2019-016 & $14.10 \mathrm{de}$ & $234.48 \mathrm{de}$ & $7.8 \mathrm{~cd}$ & $61.58 \mathrm{~cd}$ & $4.59 \mathrm{bc}$ & $5.30 \mathrm{de}$ \\
PKHT-2019-017 & $32.20 \mathrm{~b}$ & $510.93 \mathrm{~b}$ & $16.8 \mathrm{a}$ & $64.73 \mathrm{~cd}$ & $4.62 \mathrm{bc}$ & $7.21 \mathrm{ab}$ \\
MEDIANS & $24.37 \mathrm{bc}$ & $416.28 \mathrm{bc}$ & $12.3 \mathrm{~b}$ & $80.29 \mathrm{c}$ & $4.74 \mathrm{bc}$ & $5.90 \mathrm{~cd}$ \\
INTAN & $24.65 \mathrm{bc}$ & $368.88 \mathrm{bcd}$ & $6.5 \mathrm{~d}$ & $109.5 \mathrm{~b}$ & $5.23 \mathrm{~b}$ & $7.75 \mathrm{a}$ \\
\hline Uji F & $* *$ & $* *$ & $* *$ & $* *$ & $* *$ & $* *$
\end{tabular}

Keterangan: Angka-angka pada kolom yang sama yang diikuti oleh huruf yang sama tidak berbeda nyata pada DMRT taraf $\alpha=5 \%$, tn $=$ tidak berpengaruh nyata, $* *=$ berpengaruh sangat nyata 
membutuhkan umbi dengan bobot per umbi 101-300 g dengan diameter 5-7 cm (Thoriq, 2018). Pada penelitian ini tidak semua genotipe menghasilkan umbi dengan kriteria bobot maupun diameter yang sesuai dengan kriteria industri (Tabel 4). Genotipe kentang IPB yang memenuhi kriteria tersebut adalah PKHT-2019-015 dan varietas Intan. PKHT2019-015 memiliki bobot umbi terbesar pada kelas L dan XL adalah PKHT-2019-015 (121.14 g) sebesar 73\% yang tidak berbeda nyata dengan varietas Intan $(106.93 \mathrm{~g})$ sebesar $61.5 \%$. Tiga genotipe yang sebelumnya memiliki kesesuaian dengan kriteria kentang industri berdasarkan kandungan gula
(PKHT-2019-010, PKHT-2019-012, dan PKHT-2019-017) tidak menghasilkan bobot tumbi dan diameter umbi yang sesuai kriteria industri (Tabel 5). Namun demikian ketiga genotipe tersebut tidak berbeda nyata dibandingkan dengan varietas Medians yang telah sebelumnya dikenal sebagai kentang yang memenuhi kriteria industri. Peningkatan ukuran dan bobot tumbi dapat dilakukan melalui optimasi jarak tanam (Struik et al., 1990). Pada penelitian ini semua genotipe menggunakan jarak tanam yang sama, padahal PKHT-2019-017 dan PKHT-2019-017 memiliki produktivitas yang jauh lebih tinggi. Dengan demikian besar

Tabel 4. Bobot dan persentase umbi kentang hasil grading

\begin{tabular}{lccccccccccc}
\hline \multirow{2}{*}{ Genotipe } & \multicolumn{4}{c}{ Bobot umbi hasil grading $(\mathrm{g})^{\mathrm{a}}$} & \multicolumn{3}{c}{${\text { Persentase umbi }(\%)^{\mathrm{a}}}$} \\
\cline { 2 - 11 } & $\mathrm{XL}^{\mathrm{b}}$ & $\mathrm{L}$ & $\mathrm{M}$ & $\mathrm{S}$ & $\mathrm{XS}$ & $\mathrm{XL}^{\mathrm{b}}$ & $\mathrm{L}$ & $\mathrm{M}$ & $\mathrm{S}^{\mathrm{b}}$ & $\mathrm{XS}^{\mathrm{b}}$ \\
\hline PKHT-2019-010 & $69.95 \mathrm{~cd}$ & 33.82 & 24.56 & 14.52 & 8.26 & $29.00 \mathrm{bc}$ & 14.30 & 21.00 & $19.80 \mathrm{ab}$ & $16.00 \mathrm{bcd}$ \\
PKHT-2019-011 & $62.84 \mathrm{~cd}$ & 36.13 & 24.10 & 14.20 & 7.49 & $31.50 \mathrm{bc}$ & 10.80 & 13.00 & $17.00 \mathrm{ab}$ & $27.80 \mathrm{a}$ \\
PKHT-2019-012 & $63.29 \mathrm{~cd}$ & 34.81 & 25.29 & 14.52 & 6.31 & $30.50 \mathrm{bc}$ & 18.50 & 18.80 & $17.80 \mathrm{ab}$ & $14.50 \mathrm{bcd}$ \\
PKHT-2019-013 & $67.03 \mathrm{~cd}$ & 35.03 & 25.13 & 14.33 & 7.07 & $16.00 \mathrm{c}$ & 20.00 & 17.30 & $29.80 \mathrm{a}$ & $17.30 \mathrm{bc}$ \\
PKHT-2019-014 & $55.62 \mathrm{~d}$ & 32.56 & 26.55 & 14.49 & 6.17 & $23.30 \mathrm{bc}$ & 17.80 & 10.30 & $25.80 \mathrm{a}$ & $23.50 \mathrm{ab}$ \\
PKHT-2019-015 & $121.14 \mathrm{a}$ & 33.34 & 26.14 & 15.33 & 8.66 & $73.00 \mathrm{a}$ & 4.50 & 9.80 & $7.00 \mathrm{bc}$ & $5.80 \mathrm{~d}$ \\
PKHT-2019-016 & $72.73 \mathrm{~cd}$ & 33.60 & 25.39 & 14.50 & 7.58 & $37.00 \mathrm{~b}$ & 13.30 & 18.80 & $17.00 \mathrm{ab}$ & $14.80 \mathrm{bcd}$ \\
PKHT-2019-017 & $66.25 \mathrm{~cd}$ & 34.44 & 24.58 & 16.40 & 6.05 & $31.80 \mathrm{bc}$ & 14.30 & 19.50 & $18.00 \mathrm{ab}$ & $16.50 \mathrm{bcd}$ \\
MEDIANS & $91.46 \mathrm{bc}$ & 34.55 & 24.47 & 14.52 & 4.99 & $28.80 \mathrm{bc}$ & 13.50 & 14.50 & $28.30 \mathrm{a}$ & $15.30 \mathrm{bcd}$ \\
INTAN & $106.93 \mathrm{ab}$ & 31.58 & 26.28 & 12.90 & 6.05 & $61.50 \mathrm{a}$ & 13.50 & 13.50 & $2.80 \mathrm{c}$ & $8.50 \mathrm{~cd}$ \\
\hline Uji F & $* *$ & tn & tn & tn & tn & $* *$ & tn & tn & $* *$ & $* *$
\end{tabular}

Keterangan: ${ }^{a}$ Kelas umbi $\mathrm{XL}>40$ g per umbi; $\mathrm{L}=30-40$ g per umbi; $\mathrm{M}=20-30$ g per umbi; $\mathrm{S}=10-20$ g per umbi. ${ }^{\mathrm{b}}$ Angka-angka pada kolom yang sama yang diikuti oleh huruf yang sama tidak berbeda nyata pada DMRT taraf $\alpha=5 \%$, tn $=$ tidak berpengaruh nyata, $* *=$ berpengaruh sangat nyata

Tabel 5. Diameter umbi kentang hasil grading

\begin{tabular}{lcccccccccccc}
\hline \multirow{2}{*}{ Genotipe } & \multicolumn{1}{c}{ Diameter umbi berdasatkan hasil grading $(\mathrm{cm})$} & \multicolumn{5}{c}{ Persentase diameter berdasarkan hasil grading $(\%)$} \\
\cline { 2 - 12 } & XL & L & M & S & XS & XXS & XL & L & M & S & XS & XXS \\
\hline PKHT-010 & $6.23 \mathrm{a}$ & $5.35 \mathrm{ab}$ & 4.42 & 3.98 & -- & -- & $22.78 \mathrm{~b}$ & $16.6 \mathrm{~cd}$ & $34.83 \mathrm{ab}$ & $25.78 \mathrm{~b}$ & -- & -- \\
PKHT-011 & -- & $5.09 \mathrm{bc}$ & 4.05 & 3.63 & $2.01 \mathrm{~b}$ & -- & -- & $24.1 \mathrm{abc}$ & $24.08 \mathrm{abc}$ & $39.63 \mathrm{ab}$ & $12.18 \mathrm{~b}$ & -- \\
PKHT-012 & $6.11 \mathrm{a}$ & $5.41 \mathrm{ab}$ & 4.41 & 3.53 & -- & -- & $14.5 \mathrm{~b}$ & $13.25 \mathrm{~d}$ & $29.75 \mathrm{abc}$ & $42.50 \mathrm{a}$ & -- & -- \\
PKHT-013 & -- & $5.05 \mathrm{c}$ & 4.25 & 3.51 & $2.52 \mathrm{ab}$ & -- & -- & $17.13 \mathrm{bcd}$ & $17.13 \mathrm{bc}$ & $39.8 \mathrm{ab}$ & $25.93 \mathrm{a}$ & -- \\
PKHT-014 & -- & -- & 4.06 & 3.61 & $2.97 \mathrm{a}$ & 1.85 & -- & -- & $20.58 \mathrm{abc}$ & $32.18 \mathrm{ab}$ & $32.88 \mathrm{a}$ & 14.38 \\
PKHT-015 & $6.78 \mathrm{a}$ & $5.56 \mathrm{a}$ & 4.00 & 1.91 & -- & -- & $47.98 \mathrm{a}$ & $32.18 \mathrm{a}$ & $13.18 \mathrm{c}$ & $6.70 \mathrm{c}$ & -- & -- \\
PKHT-016 & $6.02 \mathrm{a}$ & $5.37 \mathrm{ab}$ & 4.61 & 3.77 & -- & -- & $13.45 \mathrm{bc}$ & $28.6 \mathrm{a}$ & $33.83 \mathrm{ab}$ & $24.13 \mathrm{~b}$ & -- & -- \\
PKHT-017 & $6.29 \mathrm{a}$ & $5.31 \mathrm{abc}$ & 4.34 & 3.66 & -- & --- & $15.3 \mathrm{~b}$ & $14.8 \mathrm{~cd}$ & $37.73 \mathrm{a}$ & $32.20 \mathrm{ab}$ & -- & -- \\
MEDIANS & $6.18 \mathrm{a}$ & $5.52 \mathrm{a}$ & 4.51 & 3.56 & -- & -- & $13.1 \mathrm{bc}$ & $26.7 \mathrm{ab}$ & $27.23 \mathrm{abc}$ & $33.03 \mathrm{ab}$ & -- & -- \\
INTAN & $6.39 \mathrm{a}$ & $5.54 \mathrm{a}$ & 4.59 & -- & -- & -- & 25.75 & $31.18 \mathrm{a}$ & $38.65 \mathrm{a}$ & $4.40 \mathrm{c}$ & -- & -- \\
\hline Uji F & $* *$ & $* *$ & tn & tn & $* *$ & tn & $* *$ & $* *$ & $*$ & $* *$ & $* *$ & tn \\
\hline
\end{tabular}

Keterangan: ${ }^{a} \mathrm{XL}=6->7 \mathrm{~cm} ; \mathrm{L}=5-5.9 \mathrm{~cm} ; \mathrm{M}=4-4.9 \mathrm{~cm} ; \mathrm{S}=3-3.9 \mathrm{~cm} ; \mathrm{XS}=2-2.9 \mathrm{~cm} ; \mathrm{XXS}=<2 \mathrm{~cm}$. ${ }^{\mathrm{b}}$ Angka-angka pada kolom yang sama yang diikuti oleh huruf yang sama tidak berbeda nyata pada DMRT taraf $\alpha=5 \%$, $\mathrm{n}=$ tidak berpengaruh nyata, $* *=$ berpengaruh sangat nyata, -- = tidak terdapat ukuran diameter umbi pada kelas tersebut 
kemungkinan bobot dan diameter umbi PKHT-2019-010 dan PKHT-2019-017 dapat ditingkatkan untuk mencapai ukuran yang sesuai dengan kriteria industri.

\section{Bentuk Umbi dan Uji Organoleptik Keripik Kentang}

Bentuk umbi berbeda-beda tiap genotipe (Gambar 1). Menurut Haqq (2020), industri keripik membutuhkan kentang berbentuk oval, sedangkan kentang goreng berbentuk panjang. Berdasarkan Tabel 6 kriteria sesuai untuk keripik kentang, yaitu genotipe berbentuk oval seperti PKHT-2019-010 dan PKHT-2019-017 karena tidak berbeda dengan bentuk umbi varietas Medians. Bentuk umbi PKHT-
2019-012 (sangat panjang) dan PKHT-2019-014 (panjang) sesuai dengan kriteria untuk kentang goreng namun dapat dimanfaatkan juga untuk keripik kentang.

Kulit umbi PKHT-2019-010, PKHT-2019-012, PKHT-2019-016, dan PKHT-2019-017 berwarna merah, PKHT-2019-011 ungu tua, PKHT-2019-013, PKHT-2019014, Intan dan Medians berwarna kekuningan. Daging umbi rata-rata berwarna kuning kecuali PKHT-2019-011 yang memiliki warna keunguan. Keripik kentang menunjukkan warna antara putih kekuningan sampai kuning kecoklatan, kecuali PKHT-2019-011 memiliki warna berbeda, yaitu ungu (Gambar 2). PKHT-2019-015, PKHT-2019-016, dan Intan mimiliki warna keripik kuning kecoklatan sehingga

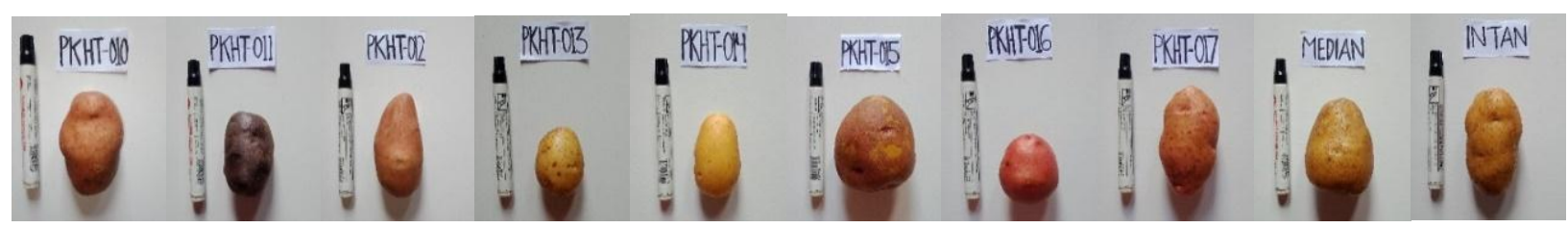

Gambar 1. Keragaan umbi kentang genotipe IPB dan dua varietas pembanding

Tabel 6. Bentuk umbi, warna kulit umbi, warna daging umbi, dan warna keripik kentang

\begin{tabular}{lllll}
\hline Genotipe & Bentuk umbi & Warna kulit umbi & Warna daging umbi & Warna keripik \\
\hline PKHT-2019-010 & Oval panjang & 35C brick-red & 5C yellow & 3C yellow \\
PKHT-2019-011 & Oval panjang & N92A violet-blue & 79B dark purple & 91A purple \\
PKHT-2019-012 & Sangat panjang & N34C orange-red & 4B yellow & 4B yellow \\
PKHT-2019-013 & Oval pendek & 9B yellow & 5C yellow & 3C yellow \\
PKHT-2019-014 & Panjang & 11A yellow-orange & 8A vivid-yellow & 7B yellow \\
PKHT-2019-015 & Oval pendek & 166B greyed-orange & 5C yellow & 7C yellow \\
PKHT-2019-016 & Oval pendek & 59A red-purple & 5C yellow & 6C yellow \\
PKHT-2019-017 & Oval panjang & 35C brick-red & 5C yellow & 4B yellow \\
MEDIANS & Oval pendek & 12B brilliant-yellow & 4C yellow green & 2C pale-yellow \\
INTAN & Oval & 162A grayed-yellow & 7D yellow & 7C yellow \\
\hline
\end{tabular}

Keterangan: Bentuk umbi berdasarkan UPOV (2004); warna: Royal Horticulture Society Color Chart

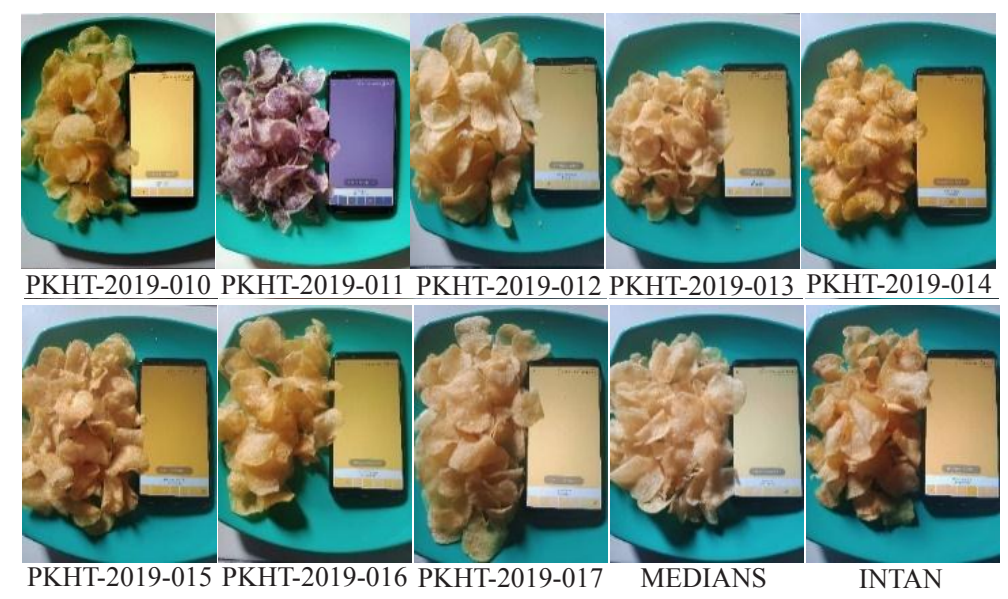

Gambar 2. Keragaan keripik kentang genotipe IPB dan dua varietas pembanding 
tidak sesuai untuk olahan. Perubahan warna kecoklatan pada hasil penggorengan keripik kentang disebabkan oleh reaksi antara gula reduksi dan protein pada suhu panas (Haryanti et al., 2013). Kandungan gula reduksi pada kentang dipengaruhi oleh varietas dan kultur teknis (Sofiari, 2009). Warna yang diharapkan oleh responden untuk keripik kentang adalah kuning cerah sampai putih. Penampilan keripik PKHT-2019-010, PKHT-2019-012, dan PKHT2019-017 menunjukkan warna kuning terang mendekati warna keripik varietas Medians sebagai kentang olahan.

\section{KESIMPULAN}

Genotipe PKHT-2019-010, PKHT-2019-012, dan PKHT-2019-017 memiliki potensi sebagai genotipe yang dapat dikembangkan sebagai varietas kentang untuk bahan baku industri keripik kentang berdasarkan berat jenis, kandungan gula, bentuk, penampilan dan warna keripik yang baik. Namun demikian masih diperlukan penelitian lanjutan untuk meningkatkan bobot dan ukuran ketiga genotipe tersebut untuk mencapai standard industri. Genotipe PKHT2019-015 memiliki produktivitas, bobot umbi dan diameter umbi yang sangat baik dan memenuhi kriteria industri, namun memiliki kadar gula yang tinggi sehingga lebih cocok dikembangkan sebagai kentang sayur.

\section{DAFTAR PUSTAKA}

Amarullah, M.R., Sudarsono, S. Amarillis. 2019. Produksi dan budidaya umbi bibit kentang (Solanum tuberosum L.) di Pangalengan, Bandung, Jawa Barat. Bul. Agrohorti. 7:93-99.

Asgar, A., S.T. Rahayu, M. Kusmana, E. Sofiari. 2011. Uji kualitas beberapa klon kentang untuk keripik. J. Hort. 21:51-59.

Asgar, A. 2013. Kualitas umbi beberapa klon kentang (Solanum tuberosum L.) dataran medium untuk keripik kentang. Berita Biologi 12:29-37.

Asgar, A., S.T. Rahayu, M. Kusmana, E. Sofiari. 2016. Uji kualitas umbi beberapa klon kentang untuk keripik. J. Hort. 21:51-59.

Duaja, M.D. 2012. Analisis umbi kentang (Solanum tuberosum L.) di dataran rendah. J. Bioplantae 1:8897.

Gunarto, A. 2012. Preferensi panelis pada tiga klon kentang terhadap kultivar Granola dan Atlantik. J. Sains dan Teknologi Indonesia 14:6-11.

Haqq, M.H. 2020. Uji daya hasil dan karakterisasi genotipe kentang (Solanum tuberosum L.) IPB di daerah Garut, Jawa Barat. Skripsi. Fakultas Pertanian. Institut Pertanian Bogor. Bogor.
Harahap, S.E., Y.A. Purwanto, S. Budijanto, A. Maharijaya. 2018. Karakterisasi kerenyahan dan kekerasan beberapa genotipe kentang (Solanum tuberosum L.) hasil pemuliaan. J. Pangan 26:1-7.

Haryanti, P., B. Sustriawan, Sujiman. 2013. Perendaman dalam kalsium klorida dan penggunaan edible coating untuk meningkatkan kualitas french fries dari kentang varietas Tenggo dan Krespo. J. Agritech. 33:38-45.

Hidayat, Y.S., D. Efendi, Sulasih. 2018. Karakterisasi morfologi beberapa genotipe kentang (Solanum tuberosum L.) yang dibudidayakan di Indonesia. J. Comm. Hort. 2:28-34.

[Kementan] Kementrian Pertanian. 2017. Statistik Pertanian 2017. http://pangan.litbang.pertanian.go.id/ [24 Maret 2020].

[Kementan] Kementrian Pertanian. 2019. Statistik Pertanian 2019. http://pangan.litbang.pertanian.go.id/ [ [1 Juli 2020].

Kurniawan, H., T. Suganda. 2014. Uji kualitas ubi beberapa klon kentang hasil persilangan untuk bahan baku keripik. J. Agro. 1:34-43.

Kusandriani, Y. 2014. Uji daya hasil dan kualitas delapan genotipe kentang untuk industri keripik kentang nasional berbahan baku lokal. J. Hort. 24:283-288.

Kusamana, R.S. Basuki. 2004. Produksi dan mutu umbi klon kentang dan kesesuaiannya sebagai bahan baku kentang goreng dan keripik kentang. J. Hort. 14:246252.

Kusmana. 2012. Uji adaptasi klon kentang hasil persilangan varietas Atlantik sebagai bahan baku keripik kentang di dataran tinggi Pangalengan. J. Hort. 22:342-348.

Mendei, J.H., A.M. Nuryadi. 2017. Pengaruh cara perendaman dan jenis kentang terhadap mutu keripik kentang. J. Penelitian Teknologi Industri 9:123-136.

Neni, N. 2017. Keragaan produksi kentang G2 genotipe IPB asal stek dan umbi di Garut Jawa Barat. Skripsi. Fakultas Pertanian. Institut Pertanian Bogor. Bogor.

Neni, N., A. Maharijaya, M. Syukur. 2018. Keragaan produksi kentang G2 genotipe IPB asal stek dan umbi di Garut Jawa Barat. Bul. Agrohort. 6:397-404.

Purwito, A., G.A. Wattimena. 2008. Kombinasi persilangan dan seleksi in vitro untuk mendapat kultivar unggul kentang. J. Ilmu Pengetahuan Indonesia 13:140149. 
Sabarella, W.B. Komalasari, S. Wahyuningsih, M. Manurung, Sehusman, Y. Supriati, Rinawati. 2017. Konsumsi dan neraca penyediaan penggunaan kentang. Bul. Konsumsi Pangan 8:31-36.

Sofiari, E. 2009. Daya hasil beberapa klon kentang di Garut. J. Hort. 19:148-154.

Struik, P.C., A.J. Haverkort, D. Vreugdenhil, C.B. Bus, R. Dankert. 1990. Manipulation of tuber-size distribution of a potato crop. Potato res. 33:417-432.

Thoriq, A., R.M. Sampurno, S. Nurjanah. 2018. Analisis kinerja produksi kentang (studi kasus: Taman Teknologi Pertanian, Cikajang, Garut, Jawa Barat). J. Teknologi Agroindustri 2:55-64.

[UPOV] International Union for the Protection of New Varieties of Plants. 2004. Guidelines for the Conduct of Tests for Distinctness, Uniformity and Stability of Potato (Solanum tuberosum L.). UPOV International. Geneva, $\mathrm{CH}$.

Utami, G.R., M.S. Rahayu, Setiawan, A. 2015. Penanganan budidaya kentang (Solanum tuberosum L.) di Bandung, Jawa Barat. Bul. Agrohort. 3:105-109.

Yulian, H. 2018. Keragaan dan uji fisikokimia umbi kentang genotipe IPB hasil pemuliaan untuk bahan baku industri olahan keripik kentang. Skripsi. Fakultas Pertanian. Institut Pertanian Bogor. Bogor.

Zulkarnain, D.H., A. Maharijaya, M. Syukur. 2017. Uji daya hasil klon harapan kentang (Solanum tuberosum L.) IPB di Kabupaten Garut Jawa Barat. J. Hort. Comm. $1: 42-48$. 